\title{
Analysis of genetic structure in Melia volkensii (Gurke.) populations using random amplified polymorphic DNA
}

\author{
Runo, M.S. ${ }^{1}$, Muluvi, G.M. ${ }^{1 *}$ and D.W. Odee ${ }^{2}$ \\ ${ }^{1}$ Biochemistry Department, Kenyatta University, P. O .Box 43844, Nairobi, Kenya. \\ ${ }^{2}$ Farm Forestry Programme, Kenya Forestry Research Institute, P. O. Box 20412, Nairobi, Kenya.
}

Accepted 5 July, 2004

\begin{abstract}
Melia volkensii (Gurke.) is a popular fast growing agroforestry tree species in the East Africa's arid and semi arid lands (ASALs). The species is valued for its high quality termite resistant timber. In addition, its fruits are eaten by livestock thus making it the species of choice by small-scale farmers. However, the species has been overexploited and information on its existing gene pool is currently lacking. The present work was therefore carried out using random amplified polymorphic DNA (RAPD) markers to assess genetic diversity within and between populations in order to suggest appropriate conservation and management strategies. Eight RAPD primers generated 38 scorable polymorphic bands which were used to estimate genetic distances between populations and for construction of neighbour-joining phenograms. Analysis of Molecular Variance (AMOVA) indicated significant genetic differentiation between populations in the eastern and the coastal regions with $21.1 \%,(P<0.0002)$ of the total variation attributed to differences between these regions. There was a clear split between populations from Eastern and Coastal populations of Kenya. These differences may be due to ecogeographical association with genetic variation and should be conserved to retain the full breadth of genetic variation of the species.
\end{abstract}

Key words: Melia volkensii, random amplified polymorphic DNA, genetic variation, agroforestry species.

\section{INTRODUCTION}

Melia volkensii, belongs to the family Meliacea and is endemic in drylands of East Africa. It is fast growing and tolerant to xeric conditions (Teel, 1985; Mabberly, 1997). This multipurpose tree is valued for both its timber and non-timber products such as provision of sawn timber and poles (Stewart and Blomley, 1994). M. volkensii has been overexploited due to its high quality timber and termite resistant poles. Habitat fragmentation and loss of the species natural population is also on the increase especially in the highly settled areas.

Conservation of plant genetic diversity has recently generated a lot of interest in the tropics as a result of many years of mismanagement, adverse environment as

${ }^{*}$ Corresponding author. Tel: 810901 ext 456. Cell phone: 0722861176. Email: Gmmuluvi@avu.org. well as socio-economic changes. Population genetic theory predicts that the decrease in the genetic diversity limits a species ability to keep pace with the changing selection pressure (Young and Merriam, 1992). Plant species, especially the perennials such as trees, rely on the available genetic diversity for stability and survival under the ever-changing environments (National Research Council, 1991). Understanding species population genetic structure is essential for their conservation, planning and sustainable management (Sun et al., 1998).

Traditionally, provenance and progeny tests coupled with biometrical analysis of phenotypic traits have been the standard methods for describing and quantifying genetic variation in forest tree species (National Research Council, 1991). However, this approach, is slow, requires the establishment of expensive field trials and the traits are measured under strong environmental effects. It is particularly a slow approach when the goal is 


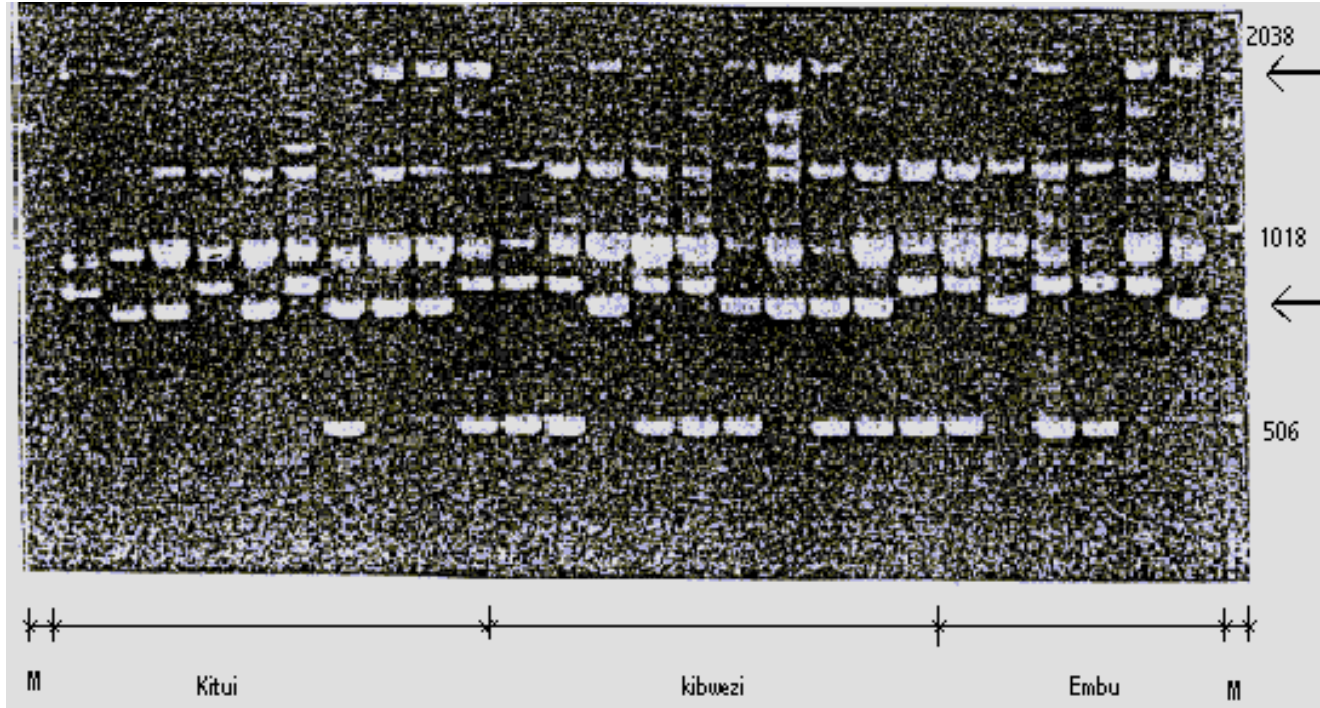

Figure 1. An example of an M. volkensii population RAPD profile generated using primer KP01. Arrows indicate some of the polymorphic bands scored.

to rapidly estimate the patterns and distribution of genetic variation for making decisions on conservation and monitoring of genetic resources. Recent development of molecular markers has complemented and drastically reduced the time taken in generating information required in making conservation and management decisions.

Maintenance of genetic diversity is considered crucial for long-term survival and evolutionary response of populations to changes in the environment (Hueneke, 1991). In addition, genetic erosion would reduce the potential of the species improvement through selection. Knowledge of genetic variation will aid in making reasoned decisions on conservation of $M$. volkensii genetic resources. Previous studies on $M$. volkensii have concentrated on drought tolerance and seed dormancy (Milimo, 1989; Milimo, 1994). In the present study, the RAPD technique (Williams et al., 1990) was used to characterize genetic variability within and between populations of $M$. volkensii.

\section{MATERIALS AND METHODS}

\section{Plant material and DNA isolation}

Leaf samples were collected from mature trees chosen at random from nine locations along the species natural distribution range in Kenya (Table 1). The sites where these populations are located differed from each other in terms of vegetation structure (species composition, richness and phenology), soil and climate (Pratt and Gwynne, 1977). Some of the populations chosen were from farmland while others were from National parks. Leaf samples were collected from 10 trees for each population bringing the total sample size to 90 . To ensure adequate preservation, leaves were dried with silica gel in snap-top plastic containers (Milligan, 1992). The method described by Edwards et al. (1991) was used to isolate total genomic DNA from M. Volkensii.

\section{RAPD reaction and Gel electrophoresis}

Amplification was carried out in a $20 \mu$ volume reaction mix, which contained $200 \mathrm{mM}$ of each of the dNTPs (Life technologies), 1X Taq polymerase buffer (Perkin Elmer), $3 \mathrm{mM} \mathrm{MgCl}_{2}$ (Perkin Elmer), $0.2 \mu \mathrm{M}$ primer (Life Technologies), $2.5 \mathrm{ng} \mathrm{\mu l}^{-1}$ DNA and 0.75 unit's of Taq polymerase (Gold ${ }^{\mathrm{TM}}$; Perkin Elmer). Amplification conditions were set as, 1 cycle of $15 \mathrm{~min}$ at $94^{\circ} \mathrm{C}, 44$ cycles of $1 \mathrm{~min}$ at $94^{\circ} \mathrm{C}$ (denaturation), $1 \mathrm{~min}$ at $36^{\circ} \mathrm{C}$ (annealing), $2 \mathrm{~min}$ at $72^{\circ} \mathrm{C}$ (extension). A final 5 min extension $\left(72^{\circ} \mathrm{C}\right.$ ) was allowed to ensure full extension of all amplified products. Amplification products were mixed with $6 \times$ gel loading dye $(0.25 \%$ bromophenol blue, $25 \%$ Xylene Cyanol and $30 \%$ glycerol) and separated on $2 \%$ agarose gel. The ethidium bromide stained agarose gels were visualised under ultra violet light and then photographed.

\section{Data analysis}

Amplification products were scored as presence or absence of a band. Diversity values were calculated according to Nei's unbiased statistic (Nei, 1987) using POPGENE 1.31 (Yeh et al., 1999). Genetic distance $(D)$ between populations were generated according to Nei (1972). Cluster analysis based on Nei's genetic distance was undertaken using an unweighted pair-group method with arithmetic averaging (UPGMA; Sneath and Sokal, 1973) to generate phenograms. Analysis of Molecular Variance (AMOVA) (Excoffier et al., 1992) was estimated using Arlequin version 2000 (Schneider et al., 2000). Significance values were assigned to variance components based on the random permutation $(5,000$ times) of individuals.

\section{RESULTS}

Analysis of the 9 populations of Melia volkensii revealed 38 polymorphic RAPD markers. An example of the molecular profile generated using primer KP01 is shown in Figure 1. Levels of genetic diversity within populations ranged from 0.0663 (Galana) to 0.1372 (Kibwezi) with a 
Table 1. The nine $M$. volkensii populations used and the mean diversity estimates $(H)$ based on 38 RAPD markers.

\begin{tabular}{llclcc}
\hline Population & GPS Readings & Altitude $(\mathbf{m})$ & Region & Population type & H \\
\hline Kitui & $01^{\circ} 30^{\prime}, 30^{\circ} 50^{\prime}$ & 1300 & Eastern & Farmland & 0.1196 \\
Kibwezi & $02^{\circ} 20^{\prime}, 38^{\circ} 57^{\prime}$ & 1200 & Eastern & Farmland & 0.1372 \\
Embu & $00^{\circ} 48^{\prime}, 37^{\circ} 55^{\prime}$ & 1050 & Eastern & Farmland & 0.0957 \\
Isiolo & $0^{\circ} 22^{\prime}, 37^{\circ} 35^{\prime}$ & 700 & Eastern & Farmland & 0.1131 \\
Meru & $0^{\circ} 00^{\prime}, 37^{\circ} 36^{\prime}$ & 1200 & Eastern & Farmland & 0.1074 \\
Mbololo & $03^{\circ} 20^{\prime}, 38^{\circ} 28^{\prime}$ & 1166 & Coast & Farmland & 0.0718 \\
Galana & $03^{\circ} 32^{\prime}, 37^{\circ} 20^{\prime}$ & 730 & Coast & National park & 0.0663 \\
Mwatate & $03^{\circ} 30^{\prime}, 38^{\circ} 30^{\prime}$ & 900 & Coast & National park & 0.0667 \\
Taveta & $03^{\circ} 37^{\prime}, 37^{\circ} 44^{\prime}$ & 1000 & Coast & National park & 0.0740 \\
\hline Mean & & & & & $\mathbf{0 . 0 9 4 6}$ \\
\hline
\end{tabular}

Table 2. Analysis of molecular variance for $M$. volkensii for the nine populations studied.

\begin{tabular}{lllll}
\hline Source of variation & d.f. & $\begin{array}{l}\text { Variance } \\
\text { component }\end{array}$ & \% variance & $\boldsymbol{P}$ values \\
\hline $\begin{array}{l}\text { Between regions } \\
\text { (Coastal and Eastern) }\end{array}$ & 1 & 0.14 & $(21.12 \%)$ & $<0.0002$ \\
Among groups & 1 & & & \\
$\begin{array}{l}\text { Between farmland and } \\
\text { Natural populations }\end{array}$ & 1 & 0.12 & $(18.8 \%)$ & $<0.0002$ \\
$\begin{array}{l}\text { Among groups } \\
\text { Among populations }\end{array}$ & & & & \\
$\begin{array}{l}\text { within groups } \\
\text { Within populations }\end{array}$ & 7 & 0.02 & $(3.49 \%)$ & $<0.0002$ \\
\hline
\end{tabular}

mean value of 0.0946 (Table 1). Comparison of genetic diversity between Eastern and Coastal populations revealed that the Eastern populations had a higher mean value of genetic diversity of 0.1146 while the mean estimate for Coastal populations was 0.0697 . When genetic diversity was considered between farmland and natural populations, it was found that a high level of genetic diversity was found in farmland (0.1075) compared to natural populations (0.0690). AMOVA analysis (Table 2 ) revealed that more variation $(75.4 \%)$ existed within populations (Table 2). There was also a high component of variation $(21.1 \%)$ existing between Coastal and Eastern populations. The dendrogram (Figure 2) showed a clear split between the Eastern and coastal populations. Further, within the coastal populations, the natural populations (Mwatate, Galana and Taveta) formed a cluster that excluded the farmland population (Mbololo).

\section{DISCUSSION}

The mean level of genetic diversity within populations $(H$ $=0.0946)($ Table 1) compared favorably to the mean level of 0.08 found by Milimo (1996) using isoenzymes in three populations (Mbololo, Embu and Isiolo) of M. volkensii. The range of genetic diversity $(0.0663$ to 0.1372$)$ compared favorably with those found in previous work by Dawson et al. (1995) in Hordeum spontaneum populations $(0.015$ to 0.237$)$. This pattern of genetic diversity may be caused and maintained by effective gene flow within populations and high fecundity. Trees that are dispersed by ingestion of seeds by animals have generally been found more variable within the populations (Loveless and Hamrick, 1984; Hamrick and Godt, 1989). M. volkensii is highly fecund with a seasonal yield of 100,000 viable seeds per tree and is dispersed by animals (Milimo, 1994) thus accounting for the high levels of variation observed.

Diversity within populations from the national parks was found to be low compared to farmland populations. This low polymorphim within National Park populations could be due to the restricted gene flow and small population size. Distribution range and population size have been identified as major correlates of within-population genetic variation in tropical tree species with restricted populations showing significantly less variation than those with broader distribution (Loveless, 1992). The 


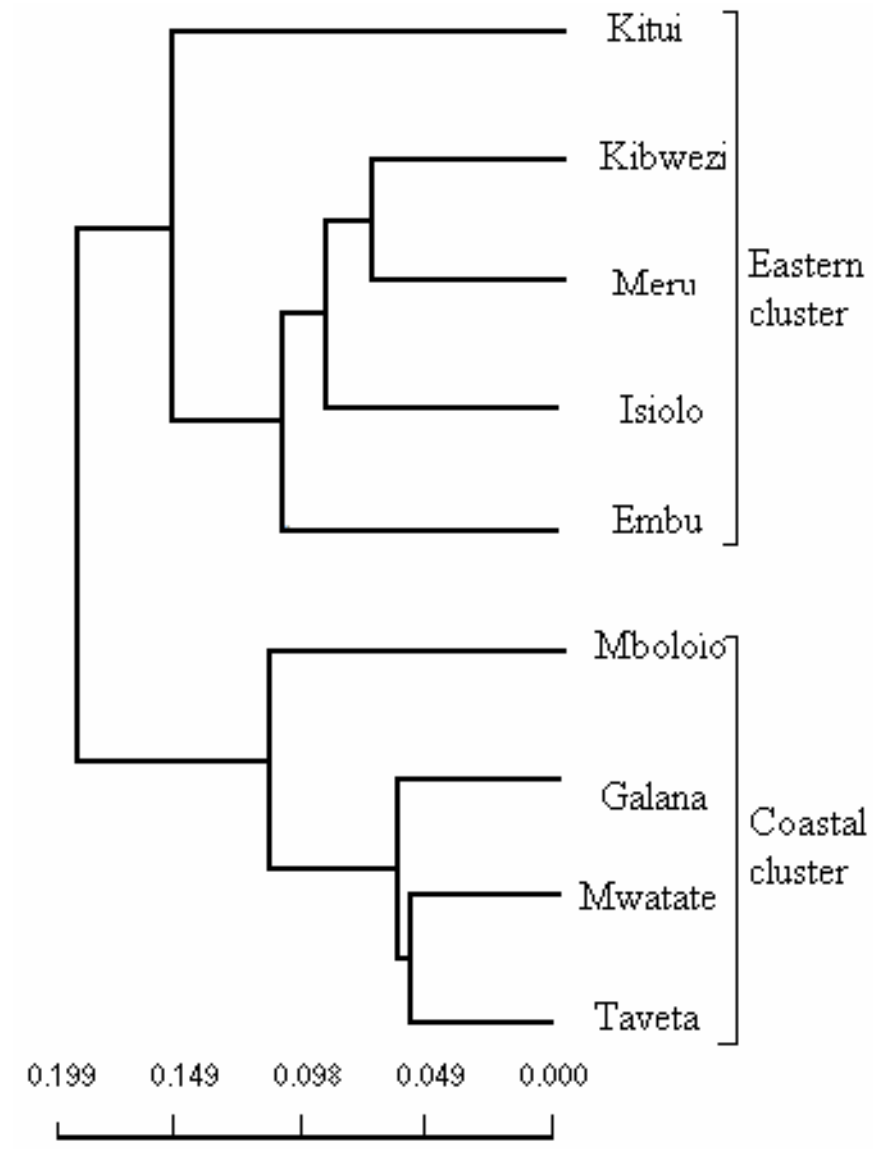

Figure 2. Dendrogram based on Nei's (1978) genetic distance for the 9 populations of $M$. volkensii based on 38 RAPD markers.

three populations (Mwatate, Galana and Taveta) are all found in the Tsavo national park. Confinement of these populations in the national reserves may also have compromised diversity due to decreased potential for long distance seed dispersal by game. Genetic diversity has also been found to vary directly with population size (Travis et al., 1996).

The natural stands continue to decline drastically and only a few still exist in the national parks (Shepherd, 1989; Riley and Bronkeshaw, 1998). The present work has shown national park populations to be less diverse. Therefore, efforts should be made to conserve the remaining stands ex situ. On farm conservation strategy of $M$. volkensii need to be emphasized since most of the variation is found on farmland populations. Major emphasis should therefore be placed on propagation and conservation of wildlings on-farm. In addition, fresh inclusions can be carried out from genetically diverse populations (Kibwezi and Kitui) to those with low genetic diversity (Galana, Taveta, Mwatate and Mbololo).

The AMOVA revealed that most of the variation $(75.4 \%)$ is found within populations (Table 2$)$. In general, predominantly outcrossed wind pollinated species have been found to exhibit most variation within populations
(Loveless, 1992; Loveless and Hamrick, 1984; Falk and Holsinger, 1991; Chase et al., 1995). The high levels of variation found within populations suggests that sampling from a few localities for either breeding or conservation could capture a large proportion of the variation within the species. Nevertheless significant variation was found between regions (eastern and coastal) and these have profound implications for conservation of $M$. volkensii. In particular, populations in these two regions need to be adequately conserved if the full breadth of genetic variation across the species range is to be maintained. Since the levels of genetic differentiation observed might be related to adaptive variation, structured progeny trials may be required to assess the performance of different populations in the different regions for traits of interest such as timber and fodder.

The significant degree of variation between the eastern and the coastal populations suggests a close association between ecogeograpical factors and RAPD variation. Similar association has been found previously in $H$. spontaneum populations by Dawson and co-workers (1993). While the eastern populations of $M$. volkensii are underlain by quaternary sedimentary and basement rocks, the coastal ones are underlain by carboniferous, Permian and Triassic rocks (Pratt and Gwynne, 1977). Rainfall is also variable between the two regions as sites along the coast have one rainy season with the maximum rainfall occurring in May. Inland, rainfall is bimodal with the first peak occurring between March and April and the second one occurring between October and November (Pratt and Gwynne, 1977). In addition, although gene flow may occur between populations the movement between the coastal and the eastern populations may be limited because of distance and disjunction in the distribution range of the species.

This is the first study to demonstrate splitting in a plant species between the eastern and coastal populations of M. volkensii in Kenya. However, Mwangi (2001) using RAPDs to study genetic variation in Prunus africana found a split between the western and the eastern populations. The split between Eastern and Coastal populations of $M$. volkensii found in the present work may be due to ecogeographical differences between the two regions.

Three coastal populations from the national park (Mwatate, Galana and Taveta) formed a cluster that excluded Mbololo. This may be due to effective gene flow among the three populations and limited gene flow with Mbololo. Whereas the three populations are confined in the national reserves, Mbololo is a farmland population and gene flow with these populations is unlikely. The eastern populations formed a similar cluster thus suggesting effective gene flow within populations. The Kitui population formed its own cluster. This was not surprising since earlier morphological data showed that the Kitui population varies from others in growth, germination and leaf margin (KEFRI, unpublished). 


\section{REFERENCES}

Chase MR, Boshier DH, Bawa KS (1995). Population genetics of Cordia alliodara (Boranginaceae), a neotropical tree. Genetic variations in nat. pop. Am. J. Bot. 82, 468-475.

Chase M, Kessel R, Bawa K (1996). Microsatelitte markers for population and conservation genetics of tropical trees. Am. J. Bot. 83, $51-57$.

Dawson IK (1995). Molecular biology and Brokenshaw 1988. The Mbeere in Kenya, Volume II, Botanical identities and uses. Inst. Anthropol., University Press of America, USA

Schneider S, Kneffer JM, Roessli D, Excoffier L (1997). Arlequin and population genetics of the tropical tree legume Gliricidia. $\mathrm{PhD}$ Thesis, Dundee University, U.K.

Dawson IK, Chalmers KJ, Waugh R, Powell W (1993). Detection and analysis of genetic variation in Hordeum spontaneum population from Israel using RAPD Markers. Mol. Eco 2, 151 - 159.

Dawson IK, Simons AJ, Waugh R, Powell W (1995). Diversitydgeneticdifferentiationamong sub-populations of Gliricidia sepium revealed by PCR-based assays. Heredity 74, $10-13$.

Edwards K, Johnson C, Thomson C (1991). A simple and rapid method for the preparation of plant genomic DNA for PCR analysis. Nucleic Acids Res. 19, 1349.

Excoffier L, Smouse PE, Quattro JM (1992). Analysis of molecular variance inferred from metric distances among DNA haplotypes: application to human mitochondrial DNA restriction data. Genetics 131, 449-491.

Falk DA, Holsinger KE (1991). Genetics and conservation of rare plants. Oxford University Press, Oxford.

Hamrick JL, Godt MJW (1989). Allozyme diversity in plant species. In: Brown A.H.D., Clegg M.T., Kahler A.L. and Weir B.S. (eds) Plant Population Genetics, Breeding and Genetic Resour. Sinauer, Sounderland, p. 4363.

Hueneke FL (1991). Ecological implication of genetic variation in plant populations. In: Falk D.A and Holsinger K.E. (eds) Genetics and Conservation of Rare Pants. Oxford University Press, New York, pp. 31-44

Loveless MD (1992). Isoenzyme variation in tropical trees: Patterns of genetic organization. New For. 6, 67-94.

Loveless MD, Hamrick JL (1984). Ecological determinants of genetic structure in populations. Ann. Rev. Ecol. Syst. 15, 65-95.

Mabberley DJ (1997). The Plant Book a Portable dictionary of the vascular plants. $2^{\text {nd }}$ Edition Cambridge University Press.

Milligan BG (1992). Plant DNA isolation. In Hoelzel, A.R. (eds) Molecular Genetic Analysis of Population. Oxford, UK IRL Press. pp. $59-88$

Milimo PB (1994). Mechanisms of Drought Resistance in Melia volkensii and Melia azedarach. PhD Thesis, Australian National University, Canberra.

Milimo PB, Hellum AK (1989). Dormancy in the seeds of Melia volkensii Gurke. East African Agric. Forestry J. 54, 111-122.
Mwangi A (2001). Genetic variation in the threatened medicinal tree Prunus africana (Hook) in Kenya and implications for the genetic management of the species. Msc. Thesis. Kenyatta University, Kenya.

National Research Council (1991). Managing global genetic resources Forest Trees National Academy Press, Washington D.C. pp 228.

Nei M (1972). Genetic distance between populations. American Naturalist 106, 283-292.

Nei M (1975). Molecular Population Genetics and Evolution. NorthHolland Publishing Company Oxford.

Nei M (1978). Estimation of average heterozygosity and genetic distance from a small number of individuals. Genetics 89, $583-590$.

Nei M (1987). Molecular Evolution Genetics, Columbia University Press, New York, USA.

Pratt DJ, Gwynne MG (1977). Rangeland management and Ecology in East Africa. Hodder and Stoughton, London. p. 310.

Riley Ver. (2000). A software for population genetic data analysis. Genet. Biom. Laboratory, University of Geneva.

Shepherd G (1989). Trees in the farming system of Mount Kenya. In: Tarltone G.L. (ed) Forestry: A Multiple-Use Enterprise, Proceedings of the Thirteenth Commonwealth Forestry Conference, Rotorua, Newzealand, pp. 224-230.

Sneath PHA, Sokal RR (1973). Numerical Taxonomy. Freeman San Francisco, United States of America.

Stewart M, Blomley T (1994). Use of Melia volkensii in a semi-arid agroforestry system in Kenya. Commonwealth Forestry Review, 73, $128-131$.

Sun M, Wong KC, Lee JSY (1998). Reproduction biology and population genetic structure of Kandelia candel (Rhizophoraceae) a viviparous mangrove species. Am. J. Bot. 85, 1631-1637.

Teel W (1985). A pocket directory of Trees and Seeds in Kenya.Published by Kenya Non-Governmental Organizations, Nairobi Kenya. p.151.

Travis SE, Maschinski J, Keim P (1996). An analysis of genetic variation in Astragalus cremnophylax var. Cremnphylax, a critically endangered plant, using AFLP markers. Mol. Ecol. 5, 735-745.

Williams JGK, Kubelik AR, Livak KI, Rafalski JA, Tingey SV (1990). DNA-Polymorphism amplified by arbitrary primers as useful as genetic markers. Nucleic Acids Res. 18, 6531 - 6535.

Yeh FC, Yang RC, Boyle T (1999). Popgene Version 1.31. University of Alberta, Canada.

Young A, Merriam HG (1992). The effect of forest fragmentation on genetic variation in an Acer saccharium. (March sugar maple) population. Paper to: International symposium on population genetics and gene conservation of forest trees. IUFRO working parties S2.04-05, S2.04-01 and S2.02.00. Carcaus Maubuuisson, France. 24-28 August 1992. 